\title{
The Effect Of Compensation On Employee Work Motivation Of Koperasi Karyawan PDAM Sidoarjo
}

\author{
Damarsari Ratnasahara Elisabeth ${ }^{1,}$ Joko Suyono $^{2,}$ Akhmad Nasir $^{3}$ \\ ${ }^{1}$ Sekolah Tinggi Ilmu Ekonomi Mahardhika, Management Department, \\ Surabaya, Indonesia. \\ ${ }^{2}$ Universitas Narotama, Department of Management and Business, \\ Surabaya, Indonesia. \\ ${ }^{3}$ Sekolah Tinggi Ilmu Ekonomi Gempol, Management Department, \\ Gempol Pasuruan, Indonesia. \\ damarsariarizona@gmail.com
}

\begin{abstract}
The object of research is Koperasi Karyawan PDAM (Drinking Water Company) Sidoarjo. This type of research is quantitative, the objective of this research is to measure the influence of independent variables and their contribution to the dependent variable, the independent variable is compensation which consist of direct compensation and indirect compensation and the dependent variable is employee motivation. Among the two independent variables, it turns out that both of them have a significant effect on employee work motivation of Koperasi Karyawan PDAM Sidoarjo. Both simultaneously and partially proved to be significant, meaning that both independent variables contributed to employee motivation.
\end{abstract}

Keywords: compensation, employee work motivation

\section{INTRODUCTION}

In the face of competition in the global era companies are required to work more efficiently and effectively. Increasingly intense competition causes companies to be required to be able to increase competitiveness in order to maintain the survival of the company.

Human resources are the most important assets of the company because of its role as the subject of implementing the company's policies and operational activities. Resources owned by companies such as capital, methods and machinery cannot provide optimum results if not supported by human resources that have optimum performance. Hartatik (2014) states that training and development are often carried out by recruiters or new and old workers as an effort to improve employee performance.

Because of the importance of the role of human resources in the company, the work motivation of each individual employee is very important. Work motivation can be done by giving an appreciation of what they have done for the company. This can be done by providing appropriate compensation to them. Because the reason for someone doing work is, among other things, to get a reward for survival and family.

However, when the company is considered lacking in providing compensation that can fulfill their cost of living, then the enthusiasm of employees in carrying out their work will also decrease. This will be very detrimental to the company if the employee has a high ability but does not want to mobilize his ability because of the lack of corporate appreciation through proper compensation (reward).

The effect of compensation on employee work motivation of Koperasi Karyawan PDAM Sidoarjo

Damarsari Ratnasahara Elisabeth' Joko Suyono' Akhmad Nasir 


\section{Formulation of the Problem}

Based on the background of the study, the authors make a problem statement as follows:

1. Does direct financial compensation $\left(\mathrm{X}_{1}\right)$ and indirect compensation $\left(\mathrm{X}_{2}\right)$ have a simultaneous effect on employee work motivation?

2. Does direct financial compensation $\left(\mathrm{X}_{1}\right)$ and indirect compensation $\left(\mathrm{X}_{2}\right)$ partially influence employee work motivation?

\section{LITERATURE REVIEW AND HYPOTHESES}

\section{Compensation}

Experts reveal various types of compensation definitions using different sentences and languages. But basically they have a similar formula for understanding compensation. Martoccio (2015) defines compensation as an intrisic and extrinsic reward received by employee after they have done their work. Mikovich (2014) stated that compansation as a reward received by employee based on anything employee has done at his/her work. William B. Wearther and Keith Davis compensation is what employee receive in exchange of their work. Whether hourly wages or periodic salaries, the personnel department usually designs and administers employee compensation (2000). According to Hariandja (2010:244) compensation is the overall remuneration received by employees as a result of carrying out work in the organization in the form of money or other, which can be in the form of salaries, wages, bonuses, incentives and other benefits such as health benefits, holiday allowances , food allowance, leave money, etc. Meanwhile Saydam (2010: 234) stated that compensation was all remuneration received by an employee or employee from his company as a result of the services or energy he had given to the company. More generally Dessler (2011: 85) states that compensation is defined as any form of payment or compensation given to employees and arises from the employment of the employee. Whereas Nawawi (2010: 315) has the opinion that compensation for an organization or company means appreciation or reward to employees who have contributed in realizing its goals, through activities called work. Financial compensation, in the form of direct and indirect financial compensation (Hasibuan, 2012). Direct financial compensation in the form of; principal fees (salaries and wages), pay fees, incentive payments (bonuses, commissions, distribution of profit / profit and stock options) and paid fees (savings and annuity programs for stock purchases). While indirect financial compensation in the form of; protection programs (health insurance, life insurance, pensions, labor insurance), fees outside working hours (holidays, holidays, annual leave and maternity leave) and facilities such as vehicles, office space and parking spaces.

\section{Motivation}

Motivation refers to "the reasons underlying behavior" (Guay et al., 2010:712). Broussard and Garrison (2004:106) broadly define motivation as "the attribute that moves us to do or not to do something". Intrinsic motivation is motivation that is animated by personal enjoyment, interest, or pleasure. As Deci et al. (1999:658) observe, "intrinsic motivation energizes and sustains activities through the spontaneous satisfactions inherent in effective volitional action. It is manifest in behaviors such as play, exploration, and challenge seeking that people often do for external rewards". Turner (1995:413) considers motivation to be synonymous with cognitive engagement, which he defines as "voluntary uses of high-level self-regulated learning strategies, such as paying attention, connection, planning, and monitoring". According to Hasibuan (2012:92) motivation comes from the Latin word "move" which means "encouragement or driving force". This means that motivating employees is the same as giving encouragement to employees to work hard and be more enthusiastic in carrying out and completing their work by using all the capabilities they have. For companies, providing motivation for employees to be able to carry out good work is not something easy,

The effect of compensation on employee work motivation of Koperasi Karyawan PDAM Sidoarjo

Damarsari Ratnasahara Elisabeth' Joko Suyono' Akhmad Nasir 
companies must be able to see employees who have the ability to carry out a job but are lazy or do not want to do the work. Because, even though a company has many reliable and capable employees, but they do not want to use these capabilities and skills, the results will not be maximized. This is in accordance with the opinion of Hasibuan (2012: 118) that employee motivation can be given to an individual who is able to do the work, but he is lazy to do those tasks by utilizing all of his abilities. For that a leader must be able to find out what the needs and wants of these employees. Because in general someone works is to fulfill all their needs and desires. This must be realized by the leadership so that it can be used as a motivator for employees to be willing to carry out their work as well as possible. With the existence of high work motivation in employees, it is expected that each individual will work hard and enthusiastically in order to achieve high productivity so that the company's goals can be achieved. According to Winardi (2009: 6) motivation is a potential force in a human being, which can be developed by itself, or by a number of outside forces which essentially revolve around monetary rewards, and non-monetary rewards, which can affect the results of their performance positively or negatively, which depends on the situation and conditions faced by the person concerned. Meanwhile according to Gray in Winardi (2009: 2) motivation is the result of a number of processes, which are internal, or external to an individual, which causes an attitude of enthusiasm and persistence to arise, in carrying out certain activities.

\section{Hypothesis}

The researcher hypothesized the problem above, namely:

1. Direct financial compensation $\left(\mathrm{X}_{1}\right)$ and indirect compensation $\left(\mathrm{X}_{2}\right)$ have a simultaneous effect on employee work motivation of Koperasi Karyawan PDAM Sidoarjo

2. Direct financial compensation $\left(\mathrm{X}_{1}\right)$ and indirect compensation $\left(\mathrm{X}_{2}\right)$ partially influence employee work motivation of Koperasi Karyawan PDAM Sidoarjo

\section{METHODS}

\section{Population and Sample}

Supardi (2012: 101) defines population as an individual or subject unit in the region and time and certain qualities that will be observed or examined. According to Subagyo (2006: 23) the population is used as a determination and limitation of the object of research so that there is no plural interpretation of all existing problems and facilitate researchers in making data retrieval that is relevant to research problems. In this study, the study population was 48 employees of Koperasi Karyawan PDAM Sidoarjo, which will be asked for information needed to solve the problems raised by the researchers.

\section{Research data}

Primary data is data taken directly from the source and has not been through the collection process from other parties. Primary data in this study were obtained through direct interviews with related parties. In addition, primary data was also obtained from questionnaires given to employees of the Koperasi Karyawan PDAM Sidoarjo Sidoarjo to be answered based on the criteria or conditions determined by the researcher.

\section{Data Analysis Techniques}

\section{Multiple Linear Regression}

Data processing tools used in this study are Multiple Linear Regression, using SPSS Version 22.0 software, and the model equation used is as follows:

$\mathrm{Y}=\mathrm{a}+\mathrm{b} 1 \mathrm{X}_{1}+\mathrm{b} 2 \mathrm{X}_{2}+\mathrm{e}$

Where :

The effect of compensation on employee work motivation of Koperasi Karyawan PDAM Sidoarjo

Damarsari Ratnasahara Elisabeth' Joko Suyono' Akhmad Nasir 
$\mathrm{Y}=$ work motivation

$\mathrm{X}_{1}=$ direct financial compensation

$\mathrm{X}_{2}=$ indirect financial compensation

$\mathrm{a}=$ constant

b1, b2, = regression coefficient

\section{RESULT AND DISCUSSION}

Results of Multiple Linear Regression Analysis

The regression equation in this study are:

$\mathrm{Y}=0.930+0.295 . \mathrm{X} 1+0.446 . \mathrm{X} 2$

Table 1: SPSS Calculations

\begin{tabular}{|c|c|c|c|c|}
\hline Variable & $\begin{array}{l}\text { Coefficient } \\
\text { Regression }\end{array}$ & $\begin{array}{l}\text { Standard } \\
\text { Error }\end{array}$ & t-count & Sig \\
\hline $\begin{array}{l}\text { Direct } \\
\text { financial } \\
\text { compensation } \\
\text { Indirect } \\
\text { financial } \\
\text { compensation }\end{array}$ & $\begin{array}{l}0.295 \\
0.446\end{array}$ & $\begin{array}{l}0.108 \\
0.090\end{array}$ & $\begin{array}{r}2.728 \\
4.926\end{array}$ & $\begin{array}{l}0.009 \\
0.000\end{array}$ \\
\hline & $\begin{array}{l}\text { Constan } \\
\text { Adj. } \mathrm{R}^{2} \\
\mathrm{R}^{2} \\
\text { Multiple R } \\
\mathrm{F} \text { - Ratio } \\
\text { Probability } \\
\text { Durbin - Wa }\end{array}$ & on & $\begin{array}{r}0.930 \\
0.627 \\
0.643 \\
0.802 \\
40.453 \\
0.000 \\
1.870\end{array}$ & \\
\hline
\end{tabular}

\section{Hypothesis Testing}

Based on the results of processing the data above using multiple linear regression analysis, the following results are obtained:

1. Significance of the F Test: $0,000<0,05$ means that the two independent variables above have a significant influence on employee work motivation variable variables at Koperasi Karyawan PDAM Sidoarjo, Sidoarjo.

2. Significance of Test $t$ : for $X_{1}$ (direct financial compensation) significance is $0.009<0.05$ and variable $\mathrm{X}_{2}$ (indirect financial compensation) significance is $0,000<0.05$, it can be decided that the two independent variables above partially have a real effect towards employee work motivasion variables at Koperasi Karyawan PDAM Sidoarjo.

The effect of compensation on employee work motivation of Koperasi Karyawan PDAM Sidoarjo

Damarsari Ratnasahara Elisabeth' Joko Suyono' Akhmad Nasir 


\section{DISCUSSION}

Direct financial compensation variable $\left(\mathrm{X}_{1}\right)$ is recorded as having a regression coefficient of 0.295 which means that if direct financial compensation $\left(\mathrm{X}_{1}\right)$ increases by one unit it will result in an increase in work motivation (Y) of 0.295 units at Koperasi Karyawan PDAM Sidoarjo. Conversely, if there is a decrease in one unit in direct financial compensation $\left(\mathrm{X}_{1}\right)$ it will result in a decrease in work motivation ( $\mathrm{Y}$ ) of 0.295 units at Koperasi Karyawan PDAM Sidoarjo, Sidoarjo. The assumption used is that other independent variables are considered constant or zero.

Indirect financial compensation variable $\left(\mathrm{X}_{2}\right)$ is recorded as having a regression coefficient of 0.446 which means that if indirect financial compensation $\left(\mathrm{X}_{2}\right)$ increases by one unit it will result in increased work motivation (Y) of 0.446 units at the Koperasi Karyawan PDAM Sidoarjo. Conversely, if there is a decrease in one unit in indirect financial compensation $\left(\mathrm{X}_{2}\right)$, it will result in a decrease in work motivation $(\mathrm{Y})$ of 0.446 units at the Koperasi Karyawan PDAM Sidoarjo. The assumption used is that other independent variables are considered constant or zero.

\section{Conclusion}

Based on the discussion that has been done about testing the effect of direct financial compensation (X1) and indirect financial compensation (X2), on the work motivation of employees of Koperasi Karyawan PDAM Sidoarjo (Y), conclusions can be drawn as folows:

1. Based on the calculation results obtained by the value of t-count for direct financial compensation of 2.728 greater than the value of $\mathrm{t}$ table 1.6794 then it can be concluded that direct financial compensation has a significant effect on employee motivation of Koperasi Karyawan PDAM Sidoarjo. This is supported by a significance value of 0.009 which is smaller than the level of significance $(\alpha)$ used at 0.05 .

2. From the calculation results show the value of t-count for indirect financial compensation amounting to 4.926 greater than the value of $\mathrm{t}$ table 1.6794 , it can be concluded that indirect financial compensation has a significant effect on employee motivation of Koperasi Karyawan PDAM Sidoarjo. This is supported by a significance value of 0,000 which is smaller than the level of significance used at 0.05 .

3. From the above calculation results at a significance level of 0.05 and $\mathrm{df}$ of 45 , the $\mathrm{F}$ table value of 3.2000 is obtained, while the calculated $\mathrm{F}$ value in this study is 40.453 . Thus it can be concluded that $\mathrm{F}$ table is smaller than $\mathrm{F}$ count, so that results can be obtained that the independent variables included in the model, namely: direct financial compensation $\left(\mathrm{X}_{1}\right)$ and indirect financial compensation $\left(\mathrm{X}_{2}\right)$ simultaneously have a significant effect.

\section{REFERENCES}

Anoraga, Panji and Ninik Widiyanti, 2011. Psychology in the Company, Jakarta: Rineka Cipta.

Arikunto, Suharsimi, 2006. Prosedur Penelitian Suatu Pendekatan Praktik. Jakarta : Rineka Cipta.

Assauri, Sofyan, 2008. Manajemen Produksi dan Operasi, Jakarta: Lembaga Penerbit Fakultas Ekonomi Universitas Indonesia.

Broussard, S. C., \& Garrison, M. E. B. (2004). The relationship between classroom motivation and academic achievement in elementary school-aged children. Family and Consumer Sciences Research Journal, 33(2), 106-120.

The effect of compensation on employee work motivation of Koperasi Karyawan PDAM Sidoarjo

Damarsari Ratnasahara Elisabeth' Joko Suyono' Akhmad Nasir 
Deci, E. L., Koestner, R., \& Ryan, R. M. (1999). A meta-analytic review of experiments examining the effects of extrinsic rewards on intrinsic motivation. Psychological Bulletin, 125(6), 627668.

Guay, F., Chanal, J., Ratelle, C. F., Marsh, H. W., Larose, S., \& Boivin, M. (2010). Intrinsic, identified, and controlled types of motivation for school subjects in young elementary school children. British Journal of Educational Psychology, 80(4), 711-735.

Hasibuan, Malayu SP, 2013. Manajemen Sumber Daya Manusia, Jakarta: Bumi Aksara.

Herdjrachman, Ranupandojo and Saud Husnan, 2000. Manajemen Personalia, Yogyakarta: BPFE UGM.

Komarudin, 2011. Manajemen Sumber Daya Manusia, Bandung: Kappa Sigma.

Martocchio, J.J., 2015. Strategic Compensaton: A Human Resource Management Approach, New Jersey: Pearson

Manullang, M, 2002. Manajemen Personalia, Jakarta: Ghalia Indonesia.

Milkovich, G., Newman, J., and Gerhant, B., 2011.Compensation, New York: McGraw-Hill Irwin

Moekiyat, 1997. Manajemen Kepegawaian, Bandung: CV. Mandar Maju

Nitisemito, Alex S, 2014. Manajemen Personalia, Jakarta: Ghalia Indonesia.

Ranupandojo and Husnan, 2000. Organisasi dan Motivasi: Pasar Peningkatan Produktivitas, Jakarta: Bumi Aksara.

Salisono, Slamet, 1993. Civil Service Administration, Jakarta.

Sedarmayanti, 2011. Manajemen Sumber Daya Manusia, Reformasi Birokrasi dan Manajemen Pegawai Negeri Sipil. Bandung : PT Refika Aditama

Susanto R and Indrio Gito Sudarmo, 1996. Manajemen Produksi, Yogyakarta: BPFE UGM.

The Liang Gie, 2002. Administrasi Perkantoran Modern, Yogyakarta: Liberty.

Turner, J. C. 1995. The influence of classroom contexts on young children's motivation for literacy. Reading Research Quarterly, 30(3), 410-441.

William B. Werther, Jr.Keith Davis, 2000. Human Resources and Personal Management. New York: Mcgraw-Hill, Inc.

Winardi, 1993. Azaz-Azaz Manajemen, Jakarta: Alumni

The effect of compensation on employee work motivation of Koperasi Karyawan PDAM Sidoarjo 